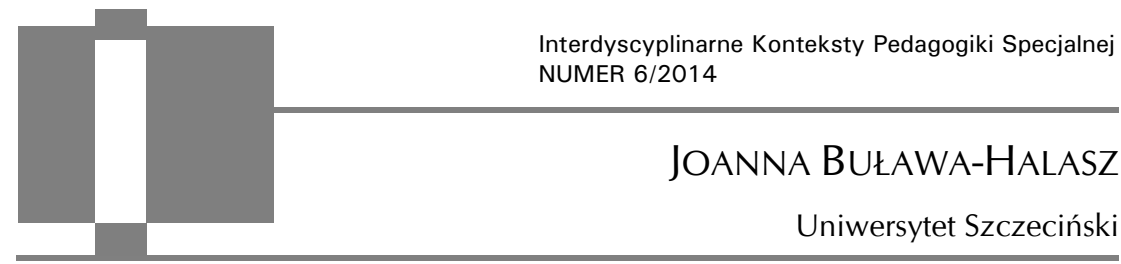

\title{
Władza symboliczna terapeutów osób autystycznych
}

\begin{abstract}
Buława-Halasz Joanna, Symbolic power of autistic people's therapists [Władza symboliczna terapeutów osób autystycznych]. Interdyscyplinarne Konteksty Pedagogiki Specjalnej, nr 6, Poznań 2014. Pp. 69-80. Adam Mickiewicz University Press. ISBN 978-83-232-2900-1. ISSN 2300-391X.

Text is conceived on the model of the puzzle, because as in the time of their first laying each element should be turned face-up and properly perceive it to fit into a whole, so each term of the Bourdieu's social theory will first be discussed separately and then complete into a larger whole through issues related to the treatment of people with autism. This article is an attempt to reinterpret the category of symbolic violence in relation to the rehabilitation of autistic people, theoretical proposition in the study of this process.
\end{abstract}

KEY WORDS: symbolic violence, habitus, doxa, capital, field

Artykuł jest próbą reinterpretacji kategorii przemocy symbolicznej w odniesieniu do rehabilitacji osób autystycznych, propozycją teoretyczną w badaniu tego procesu, która może przyczynić się do odnalezienia ukrytych mechanizmów tworzących bądź podtrzymujących dyskryminację osób autystycznych. Ta dyskryminacja może być związana z opresyjnym przekonaniem o konieczności poddania się porządkowi społecznemu wyznaczonemu przez osoby typowe. Nie ma tutaj jednak mowy o dobrowolnym „poddaństwie” ze strony osób autystycznych oraz świadomie 
podejmowanego aktu przemocy ze strony terapeutów. Wyjściem do rozważań jest myśl, że tak jak osoby "typowe" nie zawsze świadomie zachowują się w sposób "opresyjny" wobec niepełnosprawnych, tak samo terapeuci podczas terapii stosują przemoc symboliczną wobec osób autystycznych, które są na nią szczególnie narażone $\mathrm{z}$ racji trudności wynikających $\mathrm{z}$ tego zaburzenia.

Tekst jest pomyślany na wzór puzzli, bo tak jak w czynności ich układania najpierw należy odwrócić każdy element obrazkiem do góry i odpowiednio go spostrzec, żeby dopasować do całości, tak pojęcia z teorii społecznej Bourdieu zostaną najpierw kolejno omówione, a następnie złożone $\mathrm{w}$ większą całość poprzez odniesienie do zagadnienia terapii osób autystycznych. Sam autor podkreśla, że nie mogą one zostać zdefiniowane $\mathrm{w}$ stanie wyizolowanym, tylko $\mathrm{w}$ ramach systemu teoretycznego, do którego należą ${ }^{1}$ - a więc poszczególne elementy będą miały znaczenie tylko jako cały obraz.

Do głównych pojęć stosowanych przez Pierre'a Bourdieu należeć będą (w kolejności użytej w tekście): pole, habitus, przemoc symboliczna, kapitał symboliczny oraz doksa. Wszystkie one wzajemnie się uzupełniają i określają, dlatego szczególnie należy uwypuklić ich powiązania. Znajomość znaczeń tych terminów nadanym im przez Bourdieu pozwoli również na uniknięcie niewłaściwego odczytywania niniejszego opracowania - szczególnie w przypadku pojęcia "przemoc symboliczna" czy „władza symboliczna”. Intuicyjne i pierwotne jej pojmowanie może doprowadzić do potraktowania tego tekstu jako rozprawy moralizatorskiej, co byłoby największym błędem. Ona bowiem nadaje się do różnorodnego odczytu, ponieważ zajmuje "w sferze ideologii pozycję równocześnie dwuznaczną i doniosłą" 2 .

Według Bourdieu nie ma czegoś takiego jak spójne społeczeństwo, które byłoby scalone jakąś wspólną logiką społeczną, kulturą, funkcjami systemowymi, krzyżującymi się konfliktami czy chociaż-

1 P. Bourdieu, L.J.D. Wacquant, Zaproszenie do socjologii refleksyjnej, przeł. A. Sawisz, Oficyna Naukowa, Warszawa 2001, s. 76.

2 P. Bourdieu, J.-C. Passeron, Reprodukcja. Elementy teorii systemu nauczania, przeł. E. Neyman, Wyd. Nauk. PWN, Warszawa 1990, s. 54-55. 
by globalnym autorytetem - jest ono podzielone na "autonomiczne obszary gry”, które określa mianem „pola” 3 . Jest ono „na wzór pola magnetycznego, ustrukturowanym systemem sił obiektywnych, relacyjną konfiguracją wyposażoną $\mathrm{w}$ specyficzną siłę ciążenia [...], zdolną do narzucania swej wagi wszystkim przedmiotom i osobom w polu tym się znajdującym” 4 . Trzeba też pamiętać o tym, że „Każde pole stanowi potencjalnie otwarty obszar gry, którego krańce są granicami dynamicznymi i same jako takie stanowią stawkę walk wewnątrz pola"5. Najważniejszą jego funkcją jest dążenie "do zachowania bądź polepszenia swoich pozycji i do narzucenia zasady wartościowania jak najbardziej przychylnej swoim własnym wytworom. Inaczej mówiąc, strategie podmiotów działających zależą od ich pozycji w polu, czyli w systemie dystrybucji specyficznego kapitału i od ich percepcji pola. To znaczy od sposobu widzenia pola jako całości i od jego oglądu z określonego punktu widzenia wewnątrz pola"6. O co zatem toczy się gra w polu? To zależy od rodzaju pola - czy będzie nim pole naukowe, ekonomiczne, wła$\mathrm{dzy}^{7}$, czy - ukute na potrzeby tego opracowania - terapii osób autystycznych.

Czasem identyczne praktyki mogą otrzymać przeciwstawne znaczenia oraz wartości $w$ różnych polach, stanach lub $\mathrm{w}$ przeciwnych sektorach tego samego pola ${ }^{8}$. Chcąc zrozumieć, jak to się dzieje i by dobrze odczytać znaczenie pola, należałby przyjrzeć się kolejnemu terminowi, jakim jest habitus.

Habitus jest „uspołecznioną subiektywnością" ${ }^{9}$, formą zindywidualizowanego "kolektywizmu”, ale nie jest on jednostkowy, ani

${ }^{3}$ Wacquant w: P. Bourdieu, L.J.D. Wacquant, Zaproszenie do socjologii ..., dz. cyt., s. 20.

4 Tamże.

5 Tamże, s. 86-87.

6 Tamże, s. 83-84.

7 Więcej o rodzajach pól w: P. Bourdieu, Medytacje pascaliańskie, przeł. K. Wakar, Oficyna Naukowa, Warszawa 2006.

${ }^{8}$ P. Bourdieu, Dystynkcja. Społeczna krytyka władzy sądzenia, przeł. P. Biłos, Wyd. Nauk. SCHOLAR, Warszawa 2005, s. 122-123.

${ }_{9}$ P. Bourdieu, L.J.D. Wacquant, Zaproszenie do socjologii ..., dz. cyt., s. 113. 
nie wyznacza odpowiednich zachowań. Jest tylko potencjałem, zasadą generującą strategie, "mechanizmem modelującym, działającym wewnątrz jednostek, mimo że nie jest ani ściśle indywidualny, ani nie jest sam w sobie całkowitym wyznacznikiem zachowań"10. Autor wprowadza pojęcie habitusu, by zerwać z podejściem przeciwstawiającym motywy działania człowieka na dwóch przeciwległych biegunach - jako mechanicznego skutku wywołanego naciskiem przyczyn zewnętrznych albo zupełnie wolnego i świadomego ${ }^{11}$. Dyspozycja - definiuje Bourdieu - „wydaje się szczególnie nadawać do wyrażenia tego, co obejmuje pojęcie habitusu (definiowanego jako system dyspozycji) [...] predyspozycję, tendencję lub skłonność"12, które uaktywniają się w pewnej sytuacji13.

Jakie jest powiązanie pomiędzy habitusem a polem? „Konstytutywne dyspozycje wykształconego habitusu kształtują się, funkcjonują i liczą się jedynie $\mathrm{w}$ polu, w relacji z polem [...], gdzie siły objawiają się jedynie $\mathrm{w}$ relacji z niektórymi dyspozycjami"14 - dlatego właśnie takie same praktyki mogą otrzymać przeciwstawne znaczenia oraz wartości w różnych polach, stanach czy sektorach tego samego pola. Należy o tym pamiętać, interpretując to zagadnienie na potrzeby pola rehabilitacji osób autystycznych.

Znajomość habitusu jest niezbędna do zrozumienia przemocy symbolicznej określanej również dominacją bądź władzą symboliczną. Bourdieu podkreśla, że „ową szczególną formę dominacji można rozpatrywać tylko pod warunkiem rezygnacji z alternatywy przymusu za pomocą siły i zgody na racje, mechanicznego nacisku i dobrowolnego, swobodnego i świadomego podporządkowania się. Skutki dominacji symbolicznej (w dziedzinie płci, grup etnicz-

10 Wacquant w: tamże, s. 22; kursywa użyta w tekście cytowanym.

11 P. Bourdieu, Medytacje pascaliańskie, przeł. K. Wakar, Oficyna Naukowa, Warszawa 2006, s. 197-198.

12 P. Bourdieu, Szkic teorii praktyki poprzedzony trzema studiami na temat etnologii Kabylów, przeł. W. Kroker, Wyd. Marek Derewiecki, Kęty 2007, s. 193; kursywa użyta w tekście cytowanym.

13 P. Bourdieu, L.J.D. Wacquant, Zaproszenie do socjologii ..., dz. cyt., s. 123

14 P. Bourdieu, Dystynkcja ..., dz. cyt., s. 122-123. 
nych, kultury, języka itd.) nie występują w jawnej logice poznających świadomości, ale w ciemności dyspozycji habitusu, gdzie wpisane są schematy postrzegania, oceny i działania, które poza decyzjami świadomości i kontrolą woli kształtują głęboko nieświadomą samej siebie relacje praktycznego poznania i uznania. [...] Władza symboliczna jest sprawowana jedynie przy współpracy tych, którzy jej podlegają, ponieważ przyczyniają się do jej konstruowania. Nic jednak nie byłoby równie niebezpieczne jak poprzestanie na tym stwierdzeniu [...] w owym podporządkowaniu nie ma nic z relacji «dobrowolnego poddaństwa» i owe ukryte wspólnictwo nie jest zawiązane na skutek świadomego i przemyślanego aktu"15. To właśnie habitus nadaje przemocy symbolicznej jej nieświadomy charakter i podświadomą zgodę na przemoc zarówno w relacjach dominacji, jak i zdominowania: „przemoc symboliczna realizuje się w akcie poznania i nierozpoznania, pozostającym poza kontrolą świadomości i woli, w mrokach schematów wpisanych w habitus"16.

Warto podkreślić, że autor nie wyklucza istnienia obok przemocy symbolicznej również przemocy rzeczywistej/realnej: „Jedno z najczęstszych nieporozumień polega na akcentowaniu efektów czysto symbolicznych, czyli rzeczywistych skutków przemocy symbolicznej, co siłą rzeczy prowadzi do minimalizowania znaczenia aktów przemocy fizycznej: bicia, gwałtów, eksploatacji kobiet, lub gorzej, rozgrzeszania mężczyzn stosujących te formy przemocy, co nigdy nie było moim zamiarem. Ujmując «symboliczne» w opozycji do «realnego», zakładalibyśmy, że przemoc symboliczna jest pozbawioną wymiaru realności przemocą czysto «duchową». Celem materialistycznej teorii ekonomii dóbr symbolicznych, którą konstruuję od wielu lat, jest przekroczenie owego naiwnego dualizmu [...]. Chodzi więc o ukazanie obiektywnego wymiaru subiektywnego doświadczania dominacji"17.

15 P. Bourdieu, Medytacje..., dz. cyt., s. 240-243.

16 P. Bourdieu, L.J.D. Wacquant, Zaproszenie do socjologii ..., dz. cyt., s. 167.

17 P. Bourdieu, Męska dominacja, przeł. L. Kopciewicz, Oficyna Naukowa, Warszawa 2004, s. 46-47. 
Trudno byłoby zrozumieć motywy obiektów działających w polu, gdyby nie wprowadzony przez Bourdieu termin "kapita1". Za autorem wyróżnić można jego cztery główne rodzaje - ekonomiczny, kulturowy, społeczny i symboliczny ${ }^{18}$. Na potrzeby tego opracowania zostanie omówiony tylko ostatni z nich.

Kapitał symboliczny stanowią sława, szacunek, znaczenie, reputacja, uznanie. Są one podstawą „egoistycznego poszukiwania zaspokojenia «miłości własnej», które jest zarazem pełnym zapału poszukiwaniem aprobaty ze strony innej osoby"19. „Kapitał symboliczny - jak pisze Bourdieu - to zarówno kapitał materialny, jak kapitał społeczny (znajomości i ustosunkowania) oraz kapitał kulturowy"20. „Kapitał symboliczny zapewnia formy dominacji, zakładające zależność wobec tych, nad którymi pozwala dominować: $\mathrm{w}$ gruncie rzeczy istnieje on tylko w szacunku, uznaniu, zawierzeniu, zaufaniu ze strony innych osób i dzięki nim i może trwać jedynie dopóty, dopóki udaje mu się uzyskiwać wiarę w jego istnienie"21. Na kapitał symboliczny składają się między innymi tytuły, pełnione funkcje, pozycja $\mathrm{w}$ nieformalnej hierarchii pola ${ }^{22}$, ale i wszystkie świadectwa uznania społecznego, wszelkie formy bycia zauważanym, znanym, widocznym, sławnym, podziwianym, zapraszanym, lubianym itp. ${ }^{23}$ Jest on nie tyle najważniejszym ze wszystkich wyżej wymienionych kapitałów, co raczej jest najwyższą formą pozostałych. Inne w swym najbardziej ostatecznym i niejawnym celu mają ulec zamianie na kapitał symboliczny, który umożliwia sprawowania władzy symbolicznej przy użyciu przemocy symbolicznej24.

Ostatnim pojęciem - które dopełnia społeczną teorię Pierréa Bourdieu - jest doksa. Została ona zdefiniowana jako „pierwotna

18 P. Bourdieu, L.J.D. Wacquant, Zaproszenie do socjologii ..., dz. cyt., s. 104.

${ }^{19}$ P. Bourdieu, Medytacje..., dz. cyt., s. 236.

${ }^{20}$ M. Jacyno, Iluzje codzienności. O teorii socjologicznej Pierre'a Bourdieu, IFiS PAN, Warszawa 1997, s. 111.

21 P. Bourdieu, Medytacje..., dz. cyt., s. 237.

22 M. Jacyno, tamże, s. 51.

${ }^{23}$ P. Bourdieu, Medytacje..., dz. cyt., s. 345.

24 Tamże, s. 347. 
wiara” 25 . To „wiedza nienaukowa, oparta na poznaniu pozornym, nie domagająca się wyjaśnień; zakorzeniony stan pewności, nawyki mentalne"26, której immanentną cechą jest oczywistość27. „Doksa jest szczególnym punktem widzenia, punktem widzenia dominujących, który wydaje się oczywistą uniwersalną perspektywą" 28 . Jest to również zbiór "podstawowych przekonań, które nie muszą nawet występować w postaci wyraźnego i świadomego dogmatu" 29 oraz „zastanych założeń o charakterze nierozdzielnie poznawczym i oceniającym" 30 . Doksa jest "zbiorem opinii wyznawanych na zasadzie wiary przedrefleksyjnej"31. Wszelka wspólnota wartości czy interesów, akceptacja tych samych oczywistości opiera się właśnie na niej: „pierwotne doświadczenie świata społecznego to doświadczenie doksy, czyli zgody na relacje porządku, które - ponieważ leżą u podstaw świata rzeczywistego i świata myślanego - akceptowane są jako zrozumiałe same przez się"32.

Jakie jest działanie doksy? „Dyspozycje grup dominujących jawią się jako nienaznaczone, neutralne, uniwersalne oraz jednocześnie widoczne i dystynktywne lub niewidoczne i naturalne (naturalna dystynkcja), natomiast grup zdominowanych - jako «różnice», czyli negatywne znaki, braki, naznaczenia wymagające uzasadnienia. Doksa jest też obiektywną podstawą gwarantującą niekwestionowaną skuteczność wszystkim strategiom ukrywającym hipokryzję uniwersalizmu, która - posiłkując się zasadą odwróconej odpowiedzialności - nazywa każde żądanie dostępu zdominowa-

${ }^{25}$ P. Bourdieu, Zmyst praktyczny, przeł. M. Falski, Wyd. Uniwersytetu Jagiellońskiego, Kraków 2008, s. 93.

${ }^{26}$ Stownik terminologiczny, [w:] P. Bourdieu, L.J.D. Wacquant, Zaproszenie do socjologii ..., dz. cyt., s. 291.

27 P. Bourdieu, Medytacje ..., dz. cyt., s. 100; P. Bourdieu, Rozum praktyczny. O teorii działania, przeł. J. Stryjczyk, Wyd. Uniwersytetu Jagiellońskiego, Kraków, s. $104,152,166$.

28 Tamże, s. 98.

${ }^{29}$ P. Bourdieu, Medytacje ..., dz. cyt., s. 27.

30 Tamże, s. 143.

${ }^{31}$ P. Bourdieu, Dystynkcja ..., dz. cyt., s. 75.

32 Tamże, s. 578. 
nych do praw i samostanowienia partykularnym ${ }^{33}$ lub «komunotarnym» zerwaniem uniwersalnego kontraktu. Grupy zdominowane żądające uniwersalnych praw, których się im odmawia, są - paradoksalnie - natychmiast skazane na partykularyzm i «komunotaryzm»34 $[\ldots]^{\prime \prime 35}$.

Doksa to „porządek świata taki, jaki jest, z jego obowiązującymi znaczeniami i znaczeniami zakazanymi [...]. Jeszcze bardziej zadziwiające jest to, że istniejący porządek z wpisanymi weń relacjami dominacji, prawami i krzywdą, przywilejami i niesprawiedliwością utrwala się tak łatwo [...], że trudne do zniesienia warunki egzystencji traktowane są jako akceptowalne, a nawet naturalne"36.

Zanim nastąpi próba zmierzenia się puzzlami i ukazana zostanie władza symboliczna terapeutów podczas pracy z osobami autystycznymi, należałoby pokazać, że nie teoretyczne rozważania nie są zupełnie pozbawione podstaw naukowych.

Joanna Kossewska ${ }^{37}$ dokonała przeglądu badań dotyczących osób wykonujących prace związane $z$ niesieniem pomocy osobom niepełnosprawnym: nauczycieli, psychologów oraz pracowników służby zdrowia. Okazało się, że różne badania kończą się podobnymi wnioskami, mianowicie pracownicy zawodów pomocowych $\mathrm{w}$ takim samym stopniu, jak inni ludzie czują się zagubieni, gdy muszą pracować z osobą niepełnosprawną oraz że nie są wolni od stereotypów i uprzedzeń, a przecież zakłada się, iż profesjonaliści powinni być bardziej wrażliwi na potrzeby niepełnosprawnych. Z badań wynika, że lekarze, pielęgniarki czy rehabilitanci przypisują osobom niepełnosprawnym, którym pomagają, niższy status społeczny, a psychologowie różnicują swoje postawy względem zabu-

33 Partykularny oznacza nieuwzględniający interesów ogółu, dbanie o interesy własnej grupy interesu.

${ }^{34}$ Komunotaryzm - zamykanie się wspólnot.

35 P. Bourdieu, Męska ..., dz. cyt., s. 145-146.

36 Tamże, s. 7.

37 J. Kossewska, Społeczeństwo wobec osób niepetnosprawnych - postawy i ich determinanty, <http://www.wsp.krakow.pl/biblio/pliki/kossewska_01.html>, [dostęp: 09.04.2015]. 
rzeń, jakie mają ich podopieczni - bardziej pozytywne przejawiają wobec dzieci przewlekle chorych, $\mathrm{z}$ zaburzeniami sensorycznymi i trudnościami w uczeniu się niż wobec dzieci zaniedbanych, uzależnionych (od środków odurzających, alkoholu), przejawiających zaburzenia łaknienia (anoreksja/bulimia), psychotycznych, autystycznych i z nadpobudliwością psychoruchową. Ten sam profil postaw utrzymywał się wśród badanych psychologów niezależnie od zakresu osobistego kontaktu z dzieckiem niepełnosprawnym. Badania postaw wobec osób niepełnosprawnych prowadzono także wśród nauczycieli - zawodu o szczególnym znaczeniu dla kształtowania postaw kolejnych generacji dzieci i młodzieży. Postawy nauczycieli wobec niepełnosprawnych uczniów wpływają nie tylko na przystosowanie społeczne uczniów oraz efekty terapii. Nauczyciele szkół podstawowych prezentują nieprzychylne postawy wobec uczniów niepełnosprawnych, szczególnie wobec dzieci z porażeniem mózgowym i zaburzeniami emocjonalnymi. Istotną zmienną w kształtowaniu postaw nauczycieli wobec niepełnosprawnych uczniów jest kontakt i własne doświadczenie - ci, którzy podejmują osobiste kontakty $\mathrm{z}$ dziećmi niepełnoprawnymi i ich rodzinami, charakteryzują się bardziej pozytywnymi postawami niż nauczyciele, którzy takich kontaktów nie utrzymują.

Znając wyniki badań i teorię społeczną Bourdieu, można przejść do nakreślenia władzy symbolicznej terapeutów w polu terapii osób autystycznych. W polu tym nie będą przebywały same osoby autystyczne, ale również ich rodzice i terapeuci, a siłą ciążenia będzie terapia. Nie na przykład wspólne bycie, spędzanie wolnego czasu itp., ale właśnie działania - ogólnie mówiąc - „naprawcze”. O co toczy się gra w polu terapii osób autystycznych? O prowadzanie terapii, a zatem w polu terapii osób autystycznych najbardziej będzie liczył się terapeuta jako podmiot terapii - osoba aktywna, która dąży do zachowania bądź polepszenia swojej pozycji i do narzucenia zasady wartościowania jak najbardziej przychylnej swoim własnym wytworom, czyli najbardziej będzie liczyła się praca terapeuty. Osoba autystyczna jako przedmiot terapii będzie biernym jego ogniwem. Nie może ona nie zgodzić się na terapię, nie może świa- 
domie wpływać na jej kształt i ją zmieniać. Może wprawdzie stawiać opór (zarówno w formie bierności czy „zachowań trudnych”), ale wówczas on znów może zostać objęty oddziaływaniami terapeutycznymi.

Niebezpieczeństwo władzy terapeuty jest podobne do władzy nauczyciela, który „sprawuje tu najbardziej subtelną (a przez to niebezpieczną) z form władzy - mikrowładzę: rozproszoną i mało uchwytną władzę nad szczegółami, mikroelementami codziennego życia" 38 .

Mechanizm użycia przewagi i dominacji, autorytetu i przemocy pozwala nie tylko w skutkach prowadzić do usprawiedliwienia (w oczach podmiotu) istniejących stosunków siły i nierówności, ale może sam z siebie być usprawiedliwiony wtedy, gdy ten przymus sprzyja korzystnym stanom rozwojowym jednostki i grup społecznych ${ }^{39}$.

Przemoc symboliczna ma wiele wymiarów, różne stopnie nasilenia, jej mechanizmy są zróżnicowane i z jednej strony prowadzi do nieuświadomionego podporządkowania jednostki wobec zastanych struktur i znaczeń oraz prowadzi do podporządkowania im jednostki wbrew i przeciwko jej potrzebom, interesom i możliwościom rozwojowym, a z drugiej strony niesie z sobą doświadczenia prorozwojowe i może dostarczać instrumentów doświadczania podmiotowości. Przemoc symboliczna bowiem w tym przypadku nie tylko powoduje uwikłane ideologicznie sytuacje opresji wobec osoby autystycznej, ale może być czynnikiem walki z jej uprzedmiotowieniem.

Przemoc symboliczną można traktować jako „instrument adaptacji jednostki do norm grupy społecznej, do norm, reguł i przepisów organizacji w konwencjonalnym stadium rozwoju. Jednostka, przez system kar i nagród, ćwiczeń, narzucania znaczeń i uzasad-

38 Z. Melosik, T. Szkudlarek, Kultura, tożsamość i edukacja. Migotanie znaczeń, Oficyna Wydawnicza „Impuls”, Kraków 2009, s. 25.

${ }^{39} \mathrm{Z}$. Kwieciński, Ukryta przemoc jako podstawa racjonalności funkcjonowania szkoty, [w:] Socjopatologia edukacji, Trans Humana, Olecko 1995, s. 126. 
nień istniejących norm jest wyćwiczana, wdrażana, przymusem wprowadzana w świat jej realnych i potencjalnych interakcji i relacji w zastanym świecie społecznym i jego instytucjonalnych urządzeń. Zarazem jednak od wczesnych okresów rozwoju narzucane są jednostce kulturowe interpretacje przyjętych definicji dobra i zła przez instytucje zastanej przez nią dominującej (w jej «przestrzeni życiowej») religii. Tak więc i te nadrzędne - w danej, naturalnie zastanej i przekazywanej w procesach socjalizacji kulturze - kryteria wartościowania są narzucane jednostce za pośrednictwem przemocy symbolicznej pośredniczonej przez socjalizację (grup pierwotnych) i edukację (instytucji). Dopiero jednak rozwój jednostki do poziomu dyskursu znaczeń w obrębie uniwersum wartości wypracowanych w dziejach przez ludzkość i świadome kształtowanie przez jednostkę odrębnej, niepowtarzalnej tożsamości (jako symbolicznej struktury kompetencji zapewniającej ciągłość i swoistość osobowości społecznej w czasie i przestrzeni) jest taką fazą rozwoju, w której jednostka zyskuje pełnię kompetencji emancypacyjnych i komunikacyjnych, zdolność do kreowania siebie samej, swego świata społecznego i kultury" (Kwieciński 1995, s. 127).

Ale czy i na ile jest to możliwe w przypadku osób autystycznych? Jakie one mają możliwości zdobycia „pełni kompetencji emancypacyjnych", w jakim stopniu komunikacyjnych? Należy bowiem pamiętać, że zaburzenie to składa się ze swoistej triady: odchyleń od normy w zakresie interakcji społecznych, komunikacji i aktywności. Ale gdyby odwrócić sytuację i zadać sobie pytanie, co by się stało, gdyby nie podejmowano prób wobec omawianej kategorii osób, by nauczyć ich przestrzegania norm społecznych? Ten rodzaj swoistego "przymusu” zdaje się być usprawiedliwiony sam przez się, gdy służy rozwojowi jednostki. W ten sposób autor dzieli przemoc na dwie kategorie: przemoc o charakterze rozwojowym i przemoc o charakterze nierozwojowym (Kwieciński 1995, s. 126).

Tekst ten zaledwie dotyka zagadnienia, jakim jest władza symboliczna generowana przez terapeutów w toku oddziaływań terapeutycznych wobec osób autystycznych. Pozostaje wiele otwartych pytań, jak chociażby te, które stawia sam Kwieciński i nimi zostanie 
zakończony ten tekst: Jaka i do czego odnoszona przemoc może być uznana za rozwojową, a jaka za nierozwojową? Od jakiej granicy sprzyjania - niesprzyjania rozwojowi jednostki? Kto miałby definiować tę granicę oraz kryteria „sprzyjania rozwojowi”? I w końcu, jak rozumieć „rozwój”, jego wymiary, miary i kryteria?40

\section{Bibliografia}

BOURDIEU P., Dystynkcja. Społeczna krytyka władzy sadzenia, przeł. P. Biłos, Wyd. Nauk. SCHOLAR, Warszawa 2005.

BOURDIEU P., Medytacje pascaliańskie, przeł. K. Wakar, Oficyna Naukowa, Warszawa 2006.

BOURDIEU P., Męska dominacja, przeł. L. Kopciewicz, Oficyna Naukowa, Warszawa 2004.

BOURDIEU P., Rozum praktyczny. O teorii działania, przeł. J. Stryjczyk, Wyd. Uniwersytetu Jagiellońskiego, Kraków 2009.

BOURDIEU P., Szkic teorii praktyki poprzedzony trzema studiami na temat etnologii Kabylów, przeł. W. Kroker, Wyd. Marek Derewiecki, Kęty 2007.

BOURDIEU P., Zmyst praktyczny, przeł. M. Falski, Wyd. Uniwersytetu Jagiellońskiego, Kraków 2008.

BOURDIEU P., PASSERON J.-C., 1990 Reprodukcja. Elementy teorii systemu nauczania, przeł. E. Neyman, Wyd. Nauk. PWN, Warszawa.

BOURDIEU P., WACQUANT L.J.D., Zaproszenie do socjologii refleksyjnej, przeł. A. Sawisz, Oficyna Naukowa, Warszawa 2001.

JaCYNO M., Iluzje codzienności. O teorii socjologicznej Pierre'a Bourdieu, IFiS PAN, Warszawa 1997.

KOSSEWSKA J., Społeczeństwo wobec osób niepetnosprawnych - postawy $i$ ich determinan-

ty, <http://www.wsp.krakow.pl/biblio/pliki/kossewska_01.html>, [dostęp: 31.08.2014].

KWIECIŃSKI Z., Ukryta przemoc jako podstawa racjonalności funkcjonowania szkoty, [w:]

Z. Kwieciński (red.), Socjopatologia edukacji, Trans Humana, Olecko 1995.

MELOSIK Z., SZKUDLAREK T., Kultura, tożsamość i edukacja. Migotanie znaczeń, Oficyna Wydawnicza „Impuls”, Kraków 2009.

40 Tamże, s. 126. 